\title{
Nicotinic acetylcholine receptors (version 2019.4) in the IUPHAR/BPS Guide to Pharmacology Database
}

\author{
Cecilia Gotti ${ }^{1}$, Michael. J. Marks ${ }^{2}$, Neil S. Millar ${ }^{3}$ and Susan Wonnacott ${ }^{4}$ \\ 1. University of Milan, Italy \\ 2. University of Colorado, USA \\ 3. University College London, UK \\ 4. University of Bath, UK
}

\begin{abstract}
Nicotinic acetylcholine receptors are members of the Cys-loop family of transmitter-gated ion channels that includes the $\mathrm{GABA}_{A}$, strychnine-sensitive glycine and $5-\mathrm{HT}_{3}$ receptors [210, 3, 155, 220, 252]. All nicotinic receptors are pentamers in which each of the five subunits contains four $\alpha$-helical transmembrane domains. Genes encoding a total of 17 subunits $(\alpha 1-10, \beta 1-4, \gamma, \delta$ and $\varepsilon)$ have been identified [117]. All subunits with the exception of $\alpha 8$ (present in avian species) have been identified in mammals. All $\alpha$ subunits possess two tandem cysteine residues near to the site involved in acetylcholine binding, and subunits not named $\alpha$ lack these residues [155]. The orthosteric ligand binding site is formed by residues within at least three peptide domains on the $\alpha$ subunit (principal component), and three on the adjacent subunit (complementary component). nAChRs contain several allosteric modulatory sites. One such site, for positive allosteric modulators (PAMs) and allosteric agonists, has been proposed to reside within an intrasubunit cavity between the four transmembrane domains [257, 85]; see also [103]). The high resolution crystal structure of the molluscan acetylcholine binding protein, a structural homologue of the extracellular binding domain of a nicotinic receptor pentamer, in complex with several nicotinic receptor ligands (e.g.[33]) and the crystal structure of the extracellular domain of the $\alpha 1$ subunit bound to $\alpha$-bungarotoxin at $1.94 \AA$ resolution 53 ], has revealed the orthosteric binding site in detail (reviewed in $[210,117,37,193])$. Nicotinic receptors at the somatic neuromuscular junction of adult animals have the stoichiometry $(\alpha 1)_{2} \beta 1 \delta \varepsilon$, whereas an extrajunctional $(\alpha 1)_{2} \beta 1 \gamma \delta$ receptor predominates in embryonic and denervated skeletal muscle and other pathological states. Other nicotinic receptors are assembled as combinations of $\alpha(2-6)$ and \&beta(2-4) subunits. For $\alpha 2, \alpha 3, \alpha 4$ and $\beta 2$ and $\beta 4$ subunits, pairwise combinations of $\alpha$ and $\beta$ (e.g. $\alpha 3 \beta 4$ and $\alpha 4 \beta 2$ ) are sufficient to form a functional receptorin vitro, but far more complex isoforms may exist in vivo (reviewed in $[94,91,155]$ ). There is strong evidence that the pairwise assembly of some $\alpha$ and $\beta$ subunits can occur with variable stoichiometry [e.g. $(\alpha 4)_{2}(\beta 2)_{2}$ or $(\alpha 4)_{3}(\beta 2)_{2}$ ] which influences the biophysical and pharmacological properties of the receptor [155]. $\alpha 5$ and $\beta 3$ subunits lack function when expressed alone, or pairwise, but participate in the formation of functional hetero-oligomeric receptors when expressed as a third subunit with another $\alpha$ and $\beta$ pair [e.g. $\alpha 4 \alpha 5 \alpha \beta 2, \alpha 4 \alpha \beta 2 \beta 3, \alpha 5 \alpha 6 \beta 2$, see [155] for further examples]. The $\alpha 6$ subunit can form a functional receptor when co-expressed with $\beta 4$ in vitro, but more efficient expression ensues from incorporation of a third partner, such as $\beta 3$ [256]. The $\alpha 7, \alpha 8$, and $\alpha 9$ subunits form functional homo-oligomers, but can also combine with a second subunit to constitute a hetero-oligomeric assembly (e.g. $\alpha 7 \beta 2$ and $\alpha 9 \alpha 10$ ). For functional expression of the $\alpha 10$ subunit, co-assembly with $\alpha 9$ is necessary. The latter, along with the $\alpha 10$ subunit, appears to be largely confined to cochlear and vestibular hair cells. Comprehensive listings of nicotinic receptor subunit combinations identified from recombinant expression
\end{abstract}


systems, or in vivo, are given in [155]. In addition, numerous proteins interact with nicotinic ACh receptors modifying their assembly, trafficking to and from the cell surface, and activation by ACh (reviewed by [154, 9, 115]).

The nicotinic receptor Subcommittee of NC-IUPHAR has recommended a nomenclature and classification scheme for nicotinic acetylcholine ( $\mathrm{nACh}$ ) receptors based on the subunit composition of known, naturallyand/or heterologously-expressed nACh receptor subtypes [139]. Headings for this table reflect abbreviations designating nACh receptor subtypes based on the predominant $\alpha$ subunit contained in that receptor subtype. An asterisk following the indicated $\alpha$ subunit denotes that other subunits are known to, or may, assemble with the indicated $\alpha$ subunit to form the designated nACh receptor subtype(s). Where subunit stoichiometries within a specific nACh receptor subtype are known, numbers of a particular subunit larger than 1 are indicated by a subscript following the subunit (enclosed in parentheses - see also [44]).

\section{Contents}

This is a citation summary for Nicotinic acetylcholine receptors in the Guide to Pharmacology database (GtoPdb). It exists purely as an adjunct to the database to facilitate the recognition of citations to and from the database by citation analyzers. Readers will almost certainly want to visit the relevant sections of the database which are given here under database links.

GtoPdb is an expert-driven guide to pharmacological targets and the substances that act on them. GtoPdb is a reference work which is most usefully represented as an on-line database. As in any publication this work should be appropriately cited, and the papers it cites should also be recognized. This document provides a citation for the relevant parts of the database, and also provides a reference list for the research cited by those parts.

Please note that the database version for the citations given in GtoPdb are to the most recent preceding version in which the family or its subfamilies and targets were substantially changed. The links below are to the current version. If you need to consult the cited version, rather than the most recent version, please contact the GtoPdb curators.

\section{Database links}

Nicotinic acetylcholine receptors

http://www.guidetopharmacology.org/GRAC/FamilyDisplayForward?familyld=76

Introduction to Nicotinic acetylcholine receptors

http://www.guidetopharmacology.org/GRAC/FamilyIntroductionForward?familyld=76

Channels and Subunits

nicotinic acetylcholine receptor $\alpha 1$ subunit

http://www.guidetopharmacology.org/GRAC/ObjectDisplayForward?objectld=462

nicotinic acetylcholine receptor $\alpha 2$ subunit

http://www.guidetopharmacology.org/GRAC/ObjectDisplayForward?objectld=463

nicotinic acetylcholine receptor $\alpha 3$ subunit

http://www.guidetopharmacology.org/GRAC/ObjectDisplayForward?objectld=464

nicotinic acetylcholine receptor $\alpha 4$ subunit

http://www.guidetopharmacology.org/GRAC/ObjectDisplayForward?objectld=465

nicotinic acetylcholine receptor $\alpha 5$ subunit

http://www.guidetopharmacology.org/GRAC/ObjectDisplayForward?objectld=466

nicotinic acetylcholine receptor $\alpha 6$ subunit

http://www.guidetopharmacology.org/GRAC/ObjectDisplayForward?objectld=467

nicotinic acetylcholine receptor $\alpha 7$ subunit

http://www.guidetopharmacology.org/GRAC/ObjectDisplayForward?objectld=468 
nicotinic acetylcholine receptor $\alpha 8$ subunit (avian)

http://www.guidetopharmacology.org/GRAC/ObjectDisplayForward?objectld=752

nicotinic acetylcholine receptor $\alpha 9$ subunit

http://www.guidetopharmacology.org/GRAC/ObjectDisplayForward?objectld=469

nicotinic acetylcholine receptor $\alpha 10$ subunit

http://www.guidetopharmacology.org/GRAC/ObjectDisplayForward? objectld=470

nicotinic acetylcholine receptor $\beta 1$ subunit

http://www.guidetopharmacology.org/GRAC/ObjectDisplayForward?objectld=471

nicotinic acetylcholine receptor $\beta 2$ subunit

http://www. guidetopharmacology.org/GRAC/ObjectDisplayForward? objectld=472

nicotinic acetylcholine receptor $\beta 3$ subunit

http://www.guidetopharmacology.org/GRAC/ObjectDisplayForward? objectld=473

nicotinic acetylcholine receptor $\beta 4$ subunit

http://www.guidetopharmacology.org/GRAC/ObjectDisplayForward?objectld=474

nicotinic acetylcholine receptor $\mathrm{Y}$ subunit

http://www.guidetopharmacology.org/GRAC/ObjectDisplayForward?objectld=475

nicotinic acetylcholine receptor $\delta$ subunit

http://www.guidetopharmacology.org/GRAC/ObjectDisplayForward?objectld=476

nicotinic acetylcholine receptor $\varepsilon$ subunit

http://www.guidetopharmacology.org/GRAC/ObjectDisplayForward?objectld=477

\section{References}

1. Acker BA, Jacobsen EJ, Rogers BN, Wishka DG, Reitz SC, Piotrowski DW, Myers JK, Wolfe ML, Groppi VE and Thornburgh BA et al.. (2008) Discovery of N-[(3R,5R)-1-azabicyclo[3.2.1]oct-3-yl]furo[2,3c]pyridine-5-carboxamide as an agonist of the alpha7 nicotinic acetylcholine receptor: in vitro and in vivo activity. Bioorg. Med. Chem. Lett. 18: 3611-5 [PMID:18490160]

2. Adams MR, Nikkel AL, Donnelly-Roberts DL, Watt AT, Johnston JF, Cowsert LM, Butler M, Kroeger PE, Frost $L$ and Curzon $P$ et al.. (2004) In vitro and in vivo effects of an alpha3 neuronal nicotinic acetylcholine receptor antisense oligonucleotide. Brain Res. Mol. Brain Res. 129: 67-79 [PMID:15469883]

3. Albuquerque EX, Pereira EF, Alkondon M and Rogers SW. (2009) Mammalian nicotinic acetylcholine receptors: from structure to function. Physiol. Rev. 89: 73-120 [PMID:19126755]

4. Amos $\mathrm{Cl}$, Wu X, Broderick P, Gorlov IP, Gu J, Eisen T, Dong Q, Zhang Q, Gu X and Vijayakrishnan «t al.. (2008) Genome-wide association scan of tag SNPs identifies a susceptibility locus for lung cancer at 15q25.1. Nat. Genet. 40: 616-22 [PMID:18385676]

5. An MC, Lin W, Yang J, Dominguez B, Padgett D, Sugiura Y, Aryal P, Gould TW, Oppenheim RW and Hester ME et al.. (2010) Acetylcholine negatively regulates development of the neuromuscular junction through distinct cellular mechanisms. Proc. Natl. Acad. Sci. U.S.A. 107: 10702-7 [PMID:20498043]

6. Anand R and Lindstrom J. (1990) Nucleotide sequence of the human nicotinic acetylcholine receptor beta 2 subunit gene. Nucleic Acids Res. 18: 4272 [PMID:2377478]

7. Andersen N, Corradi J, Bartos M, Sine SM and Bouzat C. (2011) Functional relationships between agonist binding sites and coupling regions of homomeric Cys-loop receptors. J. Neurosci. 31: 3662-9 [PMID:21389221]

8. Anderson DJ, Bunnelle W, Surber B, Du J, Surowy C, Tribollet E, Marguerat A, Bertrand D and Gopalakrishnan M. (2008) [3H]A-585539 [(1S,4S)-2,2-dimethyl-5-(6-phenylpyridazin-3-yl)-5-aza-2azoniabicyclo[2.2.1] heptane], a novel high-affinity alpha7 neuronal nicotinic receptor agonist: radioligand binding characterization to rat and human brain. J. Pharmacol. Exp. Ther. 324: 179-87 [PMID:17959745]

9. Araud T, Wonnacott $S$ and Bertrand D. (2010) Associated proteins: The universal toolbox controlling ligand gated ion channel function. Biochem. Pharmacol. 80: 160-9 [PMID:20346921]

10. Arias HR, Richards VE, Ng D, Ghafoori ME, Le V and Mousa SA. (2009) Role of non-neuronal nicotinic acetylcholine receptors in angiogenesis. Int. J. Biochem. Cell Biol. 41: 1441-51 [PMID:19401144] 
11. Aridon P, Marini C, Di Resta C, Brilli E, De Fusco M, Politi F, Parrini E, Manfredi I, Pisano T and Pruna D et al.. (2006) Increased sensitivity of the neuronal nicotinic receptor alpha 2 subunit causes familial epilepsy with nocturnal wandering and ictal fear. Am. J. Hum. Genet.79: 342-50 [PMID:16826524]

12. Arimatsu $Y$, Seto $A$ and Amano T. (1978) Localization of alpha-bungarotoxin binding sites in mouse brain by light and electron microscopic autoradiography. Brain Res. 147: 165-9 [PMID:656911]

13. Baddick CG and Marks MJ. (2011) An auroradiographic survey of mouse brain nicotinic acetylcholine receptors defined by null mutants. Biochem. Pharmacol., [PMID:21575611]

14. Baenziger JE and Corringer PJ. (2011) 3D structure and allosteric modulation of the transmembrane domain of pentameric ligand-gated ion channels. Neuropharmacology 60: 116-25 [PMID:20713066]

15. Bailey CD, De Biasi M, Fletcher PJ and Lambe EK. (2010) The nicotinic acetylcholine receptor alpha5 subunit plays a key role in attention circuitry and accuracy. J. Neurosci. 30: 9241-52 [PMID:20610759]

16. Beeson D, Brydson M, Betty M, Jeremiah S, Povey S, Vincent A and Newsom-Davis J. (1993) Primary structure of the human muscle acetylcholine receptor. cDNA cloning of the gamma and epsilon subunits. Eur. J. Biochem. 215: 229-38 [PMID:7688301]

17. Beeson D, Brydson M and Newsom-Davis J. (1989) Nucleotide sequence of human muscle acetylcholine receptor beta-subunit. Nucleic Acids Res. 17: 4391 [PMID:2740233]

18. Bencherif M, Lovette ME, Fowler KW, Arrington S, Reeves L, Caldwell WS and Lippiello PM. (1996) RJR2403: a nicotinic agonist with CNS selectivity I. In vitro characterization. J. Pharmacol. Exp. Ther. 279: 1413-21 [PMID:8968366]

19. Bertrand D, Elmslie F, Hughes E, Trounce J, Sander T, Bertrand S and Steinlein OK. (2005) The CHRNB2 mutation I312M is associated with epilepsy and distinct memory deficits. Neurobiol. Dis. 20: 799-804 [PMID:15964197]

20. Bessis A, Simon-Chazottes D, Devillers-Thiéry A, Guénet JL and Changeux JP. (1990) Chromosomal localization of the mouse genes coding for alpha 2, alpha 3 , alpha 4 and beta 2 subunits of neuronal nicotinic acetylcholine receptor. FEBS Lett. 264: 48-52 [PMID:2338144]

21. Bitner RS, Bunnelle WH, Anderson DJ, Briggs CA, Buccafusco J, Curzon P, Decker MW, Frost JM, Gronlien JH and Gubbins E et al.. (2007) Broad-spectrum efficacy across cognitive domains by alpha7 nicotinic acetylcholine receptor agonism correlates with activation of ERK1/2 and CREB phosphorylation pathways. J. Neurosci. 27: 10578-87 [PMID:17898229]

22. Bodnar AL, Cortes-Burgos LA, Cook KK, Dinh DM, Groppi VE, Hajos M, Higdon NR, Hoffmann WE, Hurst RS and Myers JK et al.. (2005) Discovery and structure-activity relationship of quinuclidine benzamides as agonists of alpha7 nicotinic acetylcholine receptors. J. Med. Chem. 48: 905-8 [PMID:15715459]

23. Boulter J, Evans K, Goldman D, Martin G, Treco D, Heinemann S and Patrick J. (1986) Isolation of a cDNA clone coding for a possible neural nicotinic acetylcholine receptor alpha-subunit. Nature 319: 368-74 [PMID:3753746]

24. Boulter J, O'Shea-Greenfield A, Duvoisin RM, Connolly JG, Wada E, Jensen A, Gardner PD, Ballivet M, Deneris ES and McKinnon D et al.. (1990) Alpha 3, alpha 5, and beta 4: three members of the rat neuronal nicotinic acetylcholine receptor-related gene family form a gene cluster. J. Biol. Chem. 265: 4472-82 [PMID:1689727]

25. Broad LM, Felthouse C, Zwart R, McPhie GI, Pearson KH, Craig PJ, Wallace L, Broadmore RJ, Boot JR and Keenan $\mathrm{M}$ et al.. (2002) PSAB-OFP, a selective alpha 7 nicotinic receptor agonist, is also a potent agonist of the 5-HT3 receptor. Eur. J. Pharmacol. 452: 137-44 [PMID:12354563]

26. Broad LM, Zwart R, Pearson KH, Lee M, Wallace L, McPhie GI, Emkey R, Hollinshead SP, Dell CP and Baker SR et al.. (2006) Identification and pharmacological profile of a new class of selective nicotinic acetylcholine receptor potentiators. J. Pharmacol. Exp. Ther. 318: 1108-17 [PMID:16738207]

27. Broide RS, Salas R, Ji D, Paylor R, Patrick JW, Dani JA and De Biasi M. (2002) Increased sensitivity to nicotine-induced seizures in mice expressing the L250T alpha 7 nicotinic acetylcholine receptor mutation. Mol. Pharmacol. 61: 695-705 [PMID:11854451]

28. Brown RW, Collins AC, Lindstrom JM and Whiteaker P. (2007) Nicotinic alpha5 subunit deletion locally reduces high-affinity agonist activation without altering nicotinic receptor numbers. J. Neurochem. 103: 
204-15 [PMID:17573823]

29. Brownlow S, Webster R, Croxen R, Brydson M, Neville B, Lin JP, Vincent A, Newsom-Davis J and Beeson D. (2001) Acetylcholine receptor delta subunit mutations underlie a fast-channel myasthenic syndrome and arthrogryposis multiplex congenita. J. Clin. Invest. 108: 125-30 [PMID:11435464]

30. Buisson B, Gopalakrishnan M, Arneric SP, Sullivan JP and Bertrand D. (1996) Human alpha4beta2 neuronal nicotinic acetylcholine receptor in HEK 293 cells: A patch-clamp study. J. Neurosci. 16: 7880-91 [PMID:8987816]

31. Buonanno A, Mudd J and Merlie JP. (1989) Isolation and characterization of the beta and epsilon subunit genes of mouse muscle acetylcholine receptor. J. Biol. Chem. 264: 7611-6 [PMID:2708381]

32. Campbell NR, Fernandes CC, Halff AW and Berg DK. (2010) Endogenous signaling through alpha7containing nicotinic receptors promotes maturation and integration of adult-born neurons in the hippocampus. J. Neurosci. 30: 8734-44 [PMID:20592195]

33. Celie PH, van Rossum-Fikkert SE, van Dijk WJ, Brejc K, Smit AB and Sixma TK. (2004) Nicotine and carbamylcholine binding to nicotinic acetylcholine receptors as studied in AChBP crystal structures. Neuron 41: 907-14 [PMID:15046723]

34. Champtiaux N and Changeux JP. (2004) Knockout and knockin mice to investigate the role of nicotinic receptors in the central nervous system. Prog. Brain Res. 145: 235-51 [PMID:14650919]

35. Champtiaux N, Gotti C, Cordero-Erausquin M, David DJ, Przybylski C, Léna C, Clementi F, Moretti M, Rossi FM and Le Novère $\mathrm{N}$ et al.. (2003) Subunit composition of functional nicotinic receptors in dopaminergic neurons investigated with knock-out mice. J. Neurosci. 23: 7820-9 [PMID:12944511]

36. Champtiaux N, Han ZY, Bessis A, Rossi FM, Zoli M, Marubio L, McIntosh JM and Changeux JP. (2002) Distribution and pharmacology of alpha 6-containing nicotinic acetylcholine receptors analyzed with mutant mice. J. Neurosci. 22: 1208-17 [PMID:11850448]

37. Changeux JP and Taly A. (2008) Nicotinic receptors, allosteric proteins and medicine.Trends Mol Med 14: 93-102 [PMID:18262468]

38. Chavez-Noriega LE, Crona JH, Washburn MS, Urrutia A, Elliott KJ and Johnson EC. (1997) Pharmacological characterization of recombinant human neuronal nicotinic acetylcholine receptors $\mathrm{h}$ alpha 2 beta 2, h alpha 2 beta 4 , h alpha 3 beta 2, h alpha 3 beta 4 , h alpha 4 beta 2, h alpha 4 beta 4 and $\mathrm{h}$ alpha 7 expressed in Xenopus oocytes. J. Pharmacol. Exp. Ther. 280: 346-56 [PMID:8996215]

39. Chen Y, Sharples TJ, Phillips KG, Benedetti G, Broad LM, Zwart R and Sher E. (2003) The nicotinic alpha 4 beta 2 receptor selective agonist, TC-2559, increases dopamine neuronal activity in the ventral tegmental area of rat midbrain slices. Neuropharmacology 45: 334-44 [PMID:12871651]

40. Chen Y, Wu L, Fang Y, He Z, Peng B, Shen Y and Xu Q. (2009) A novel mutation of the nicotinic acetylcholine receptor gene CHRNA4 in sporadic nocturnal frontal lobe epilepsy. Epilepsy Res. 83: 152-6 [PMID:19058950]

41. Chini B, Raimond E, Elgoyhen AB, Moralli D, Balzaretti M and Heinemann S. (1994) Molecular cloning and chromosomal localization of the human alpha 7-nicotinic receptor subunit gene (CHRNA7). Genomics 19: 379-81 [PMID:8188270]

42. Cimino M, Marini $P$, Fornasari D, Cattabeni F and Clementi F. (1992) Distribution of nicotinic receptors in cynomolgus monkey brain and ganglia: localization of alpha 3 subunit mRNA, alpha-bungarotoxin and nicotine binding sites. Neuroscience 51: 77-86 [PMID:1465189]

43. Coe JW, Brooks PR, Wirtz MC, Bashore CG, Bianco KE, Vetelino MG, Arnold EP, Lebel LA, Fox CB and Tingley 3rd FD et al.. (2005) 3,5-Bicyclic aryl piperidines: a novel class of alpha4beta2 neuronal nicotinic receptor partial agonists for smoking cessation. Bioorg. Med. Chem. Lett. 15: 4889-97 [PMID:16171993]

44. Collingridge GL, Olsen RW, Peters $J$ and Spedding M. (2009) A nomenclature for ligand-gated ion channels. Neuropharmacology 56: 2-5 [PMID:18655795]

45. Corringer PJ, Le Novère $N$ and Changeux JP. (2000) Nicotinic receptors at the amino acid level Annu. Rev. Pharmacol. Toxicol. 40: 431-58 [PMID:10836143]

46. Cossins J, Webster R, Maxwell S, Burke G, Vincent A and Beeson D. (2004) A mouse model of AChR deficiency syndrome with a phenotype reflecting the human condition. Hum. Mol. Genet. 13: 2947-57 
[PMID:15471888]

47. Croxen R, Hatton C, Shelley C, Brydson M, Chauplannaz G, Oosterhuis H, Vincent A, Newsom-Davis J, Colquhoun D and Beeson D. (2002) Recessive inheritance and variable penetrance of slow-channel congenital myasthenic syndromes. Neurology 59: 162-8 [PMID:12141316]

48. Croxen R, Newland C, Beeson D, Oosterhuis H, Chauplannaz G, Vincent A and Newsom-Davis J. (1997) Mutations in different functional domains of the human muscle acetylcholine receptor alpha subunit in patients with the slow-channel congenital myasthenic syndrome. Hum. Mol. Genet. 6: 767-74 [PMID:9158151]

49. Cui C, Booker TK, Allen RS, Grady SR, Whiteaker P, Marks MJ, Salminen O, Tritto T, Butt CM and Allen WR et al.. (2003) The beta3 nicotinic receptor subunit: a component of alpha-conotoxin MII-binding nicotinic acetylcholine receptors that modulate dopamine release and related behaviors. J. Neurosci. 23: 11045-53 [PMID:14657161]

50. Dajas-Bailador F and Wonnacott S. (2004) Nicotinic acetylcholine receptors and the regulation of neuronal signalling. Trends Pharmacol. Sci. 25: 317-24 [PMID:15165747]

51. Dani JA and Bertrand D. (2007) Nicotinic acetylcholine receptors and nicotinic cholinergic mechanisms of the central nervous system. Annu. Rev. Pharmacol. Toxicol. 47: 699-729 [PMID:17009926]

52. De Fusco M, Becchetti A, Patrignani A, Annesi G, Gambardella A, Quattrone A, Ballabio A, Wanke E and Casari G. (2000) The nicotinic receptor beta 2 subunit is mutant in nocturnal frontal lobe epilepsy. Nat. Genet. 26: 275-6 [PMID:11062464]

53. Dellisanti CD, Yao Y, Stroud JC, Wang ZZ and Chen L. (2007) Crystal structure of the extracellular domain of nAChR alpha1 bound to alpha-bungarotoxin at 1.94 A resolution. Nat. Neurosci. 10: 953-62 [PMID:17643119]

54. Deneris ES, Boulter J, Swanson LW, Patrick J and Heinemann S. (1989) Beta 3: a new member of nicotinic acetylcholine receptor gene family is expressed in brain. J. Biol. Chem. 264: 6268-72 [PMID:2703489]

55. Deneris ES, Connolly J, Boulter J, Wada E, Wada K, Swanson LW, Patrick J and Heinemann S. (1988) Primary structure and expression of beta 2: a novel subunit of neuronal nicotinic acetylcholine receptors. Neuron 1: 45-54 [PMID:3272154]

56. Dinklo T, Shaban H, Thuring JW, Lavreysen H, Stevens KE, Zheng L, Mackie C, Grantham C, Vandenberk I and Meulders $G$ et al.. (2011) Characterization of 2-[[4-fluoro-3-(trifluoromethyl)phenyl]amino]-4-(4pyridinyl)-5-thiazolemethanol (JNJ-1930942), a novel positive allosteric modulator of the \{alpha\}7 nicotinic acetylcholine receptor. J. Pharmacol. Exp. Ther. 336: 560-74 [PMID:21084390]

57. Dogruer D, Lee M, Dukat M, Damaj MI, Martin BR and Glennon RA. (2004) 3-(4-Aminobutyn-1yl)pyridines: binding at alpha 4 beta 2 nicotinic cholinergic receptors. Bioorg. Med. Chem. Lett. 14: 523-6 [PMID:14698195]

58. Donnelly-Roberts DL, Puttfarcken PS, Kuntzweiler TA, Briggs CA, Anderson DJ, Campbell JE, PiattoniKaplan M, McKenna DG, Wasicak JT and Holladay MW et al.. (1998) ABT-594 [(R)-5-(2azetidinylmethoxy)-2-chloropyridine]: a novel, orally effective analgesic acting via neuronal nicotinic acetylcholine receptors: I. In vitro characterization. J. Pharmacol. Exp. Ther. 285: 777-86 [PMID:9580626]

59. Drenan RM, Grady SR, Whiteaker P, McClure-Begley T, McKinney S, Miwa JM, Bupp S, Heintz N, Mclntosh JM and Bencherif $M$ et al.. (2008) In vivo activation of midbrain dopamine neurons via sensitized, high-affinity alpha 6 nicotinic acetylcholine receptors. Neuron 60: 123-36 [PMID:18940593]

60. Drescher DG, Khan KM, Green GE, Morley BJ, Beisel KW, Kaul H, Gordon D, Gupta AK, Drescher MJ and Barretto RL. (1995) Analysis of nicotinic acetylcholine receptor subunits in the cochlea of the mouse. Comp. Biochem. Physiol. C, Pharmacol. Toxicol. Endocrinol. 112: 267-73 [PMID:8838678]

61. Dudai $Y$ and Segal M. (1978) alpha-Bungarotoxin binding sites in rat hippocampus: localization in postynaptic cells. Brain Res. 154: 167-71 [PMID:698814]

62. Duga S, Asselta R, Bonati MT, Malcovati M, Dalprà L, Oldani A, Zucconi M, Ferini-Strambi L and Tenchini ML. (2002) Mutational analysis of nicotinic acetylcholine receptor beta2 subunit gene (CHRNB2) in a representative cohort of Italian probands affected by autosomal dominant nocturnal frontal lobe epilepsy. 
Epilepsia 43: 362-4 [PMID:11952766]

63. Duvoisin RM, Deneris ES, Patrick $J$ and Heinemann S. (1989) The functional diversity of the neuronal nicotinic acetylcholine receptors is increased by a novel subunit: beta 4. Neuron 3: 487-96 [PMID:2642007]

64. Dziewczapolski G, Glogowski CM, Masliah E and Heinemann SF. (2009) Deletion of the alpha 7 nicotinic acetylcholine receptor gene improves cognitive deficits and synaptic pathology in a mouse model of Alzheimer's disease. J. Neurosci. 29: 8805-15 [PMID:19587288]

65. Egea J, Rosa AO, Sobrado M, Gandía L, López MG and García AG. (2007) Neuroprotection afforded by nicotine against oxygen and glucose deprivation in hippocampal slices is lost in alpha7 nicotinic receptor knockout mice. Neuroscience 145: 866-72 [PMID:17291692]

66. Elgoyhen AB, Johnson DS, Boulter J, Vetter DE and Heinemann S. (1994) Alpha 9: an acetylcholine receptor with novel pharmacological properties expressed in rat cochlear hair cells. Cell 79: 705-15 [PMID:7954834]

67. Elgoyhen AB, Vetter DE, Katz E, Rothlin CV, Heinemann SF and Boulter J. (2001) alpha10: a determinant of nicotinic cholinergic receptor function in mammalian vestibular and cochlear mechanosensory hair cells. Proc. Natl. Acad. Sci. U.S.A. 98: 3501-6 [PMID:11248107]

68. Elliott KJ, Ellis SB, Berckhan KJ, Urrutia A, Chavez-Noriega LE, Johnson EC, Veliçelebi G and Harpold MM. (1996) Comparative structure of human neuronal alpha 2-alpha 7 and beta 2-beta 4 nicotinic acetylcholine receptor subunits and functional expression of the alpha 2, alpha 3, alpha 4, alpha 7, beta 2 , and beta 4 subunits. J. Mol. Neurosci. 7: 217-28 [PMID:8906617]

69. Eng CM, Kozak CA, Beaudet AL and Zoghbi HY. (1991) Mapping of multiple subunits of the neuronal nicotinic acetylcholine receptor to chromosome 15 in man and chromosome 9 in mouse. Genomics 9: 27882 [PMID:2004777]

70. Engel AG, Ohno K, Bouzat C, Sine SM and Griggs RC. (1996) End-plate acetylcholine receptor deficiency due to nonsense mutations in the epsilon subunit. Ann. Neurol. 40: 810-7 [PMID:8957026]

71. Engel AG, Ohno K, Milone M, Wang HL, Nakano S, Bouzat C, Pruitt 2nd JN, Hutchinson DO, Brengman $\mathrm{JM}$ and Bren $\mathrm{N}$ et al.. (1996) New mutations in acetylcholine receptor subunit genes reveal heterogeneity in the slow-channel congenital myasthenic syndrome. Hum. Mol. Genet. 5: 1217-27 [PMID:8872460]

72. Engel AG, Ohno K and Sine SM. (2003) Congenital myasthenic syndromes: A diverse array of molecular targets. J. Neurocytol. 32: 1017-37 [PMID:15034283]

73. Engel AG, Ohno K and Sine SM. (2003) Sleuthing molecular targets for neurological diseases at the neuromuscular junction. Nat. Rev. Neurosci. 4: 339-52 [PMID:12728262]

74. Engel AG, Shen XM, Selcen D and Sine SM. (2010) What have we learned from the congenital myasthenic syndromes. J. Mol. Neurosci. 40: 143-53 [PMID:19688192]

75. Engel AG and Sine SM. (2005) Current understanding of congenital myasthenic syndromes.Curr Opin Pharmacol 5: 308-21 [PMID:15907919]

76. Fernandes C, Hoyle E, Dempster E, Schalkwyk LC and Collier DA. (2006) Performance deficit of alpha7 nicotinic receptor knockout mice in a delayed matching-to-place task suggests a mild impairment of working/episodic-like memory. Genes Brain Behav. 5: 433-40 [PMID:16923147]

77. Fischer H, Orr-Urtreger A, Role LW and Huck S. (2005) Selective deletion of the alpha5 subunit differentially affects somatic-dendritic versus axonally targeted nicotinic ACh receptors in mouse. J. Physiol. (Lond.) 563: 119-37 [PMID:15611037]

78. Fonck C, Cohen BN, Nashmi R, Whiteaker P, Wagenaar DA, Rodrigues-Pinguet N, Deshpande P, McKinney S, Kwoh S and Munoz J et al.. (2005) Novel seizure phenotype and sleep disruptions in knock-in mice with hypersensitive alpha $4^{*}$ nicotinic receptors. J. Neurosci. 25: 11396-411 [PMID:16339034]

79. Fonck C, Nashmi R, Deshpande P, Damaj MI, Marks MJ, Riedel A, Schwarz J, Collins AC, Labarca C and Lester HA. (2003) Increased sensitivity to agonist-induced seizures, straub tail, and hippocampal theta rhythm in knock-in mice carrying hypersensitive alpha 4 nicotinic receptors. J. Neurosci. 23: 2582-90 [PMID:12684443]

80. Fornasari D, Chini B, Tarroni P and Clementi F. (1990) Molecular cloning of human neuronal nicotinic receptor alpha 3-subunit. Neurosci. Lett. 111: 351-6 [PMID:2336208] 
81. Fowler CD, Arends MA and Kenny PJ. (2008) Subtypes of nicotinic acetylcholine receptors in nicotine reward, dependence, and withdrawal: evidence from genetically modified mice. Behav Pharmacol 19: 46184 [PMID:18690103]

82. Fowler CD, Lu Q, Johnson PM, Marks MJ and Kenny PJ. (2011) Habenular $\alpha 5$ nicotinic receptor subunit signalling controls nicotine intake. Nature 471: 597-601 [PMID:21278726]

83. Freedman R, Hall M, Adler LE and Leonard S. (1995) Evidence in postmortem brain tissue for decreased numbers of hippocampal nicotinic receptors in schizophrenia. Biol. Psychiatry 38: 22-33 [PMID:7548469]

84. Gault J, Robinson M, Berger R, Drebing C, Logel J, Hopkins J, Moore T, Jacobs S, Meriwether J and Choi MJ et al.. (1998) Genomic organization and partial duplication of the human alpha7 neuronal nicotinic acetylcholine receptor gene (CHRNA7). Genomics 52: 173-85 [PMID:9782083]

85. Gill JK, Savolainen M, Young GT, Zwart R, Sher E and Millar NS. (2011) Agonist activation of alpha7 nicotinic acetylcholine receptors via an allosteric transmembrane site. Proc. Natl. Acad. Sci. U.S.A. 108: 5867-72 [PMID:21436053]

86. Goldman D, Deneris E, Luyten W, Kochhar A, Patrick J and Heinemann S. (1987) Members of a nicotinic acetylcholine receptor gene family are expressed in different regions of the mammalian central nervous system. Cell 48: 965-73 [PMID:3829125]

87. Goldman D, Simmons D, Swanson LW, Patrick J and Heinemann S. (1986) Mapping of brain areas expressing RNA homologous to two different acetylcholine receptor alpha-subunit cDNAs. Proc. Natl. Acad. Sci. U.S.A. 83: 4076-80 [PMID:3012549]

88. Gomez CM, Maselli R, Gammack J, Lasalde J, Tamamizu S, Cornblath DR, Lehar M, McNamee M and Kuncl RW. (1996) A beta-subunit mutation in the acetylcholine receptor channel gate causes severe slowchannel syndrome. Ann. Neurol. 39: 712-23 [PMID:8651643]

89. Gomez CM, Maselli RA, Vohra BP, Navedo M, Stiles JR, Charnet P, Schott K, Rojas L, Keesey J and Verity A et al.. (2002) Novel delta subunit mutation in slow-channel syndrome causes severe weakness by novel mechanisms. Ann. Neurol. 51: 102-12 [PMID:11782989]

90. Gordon JC, Phillips E, Gurley DA, Heys JR, Lazor LA, Barthlow HG, Mallamaci MA and Keith RA. (2010) In vitro binding characteristics of [3H]AZ11637326, a novel alpha7-selective neuronal nicotinic receptor agonist radioligand. Eur. J. Pharmacol. 645: 63-9 [PMID:20674564]

91. Gotti C, Clementi F, Fornari A, Gaimarri A, Guiducci S, Manfredi I, Moretti M, Pedrazzi P, Pucci L and Zoli M. (2009) Structural and functional diversity of native brain neuronal nicotinic receptors. Biochem. Pharmacol. 78: 703-11 [PMID:19481063]

92. Gotti C, Moretti M, Clementi F, Riganti L, Mclntosh JM, Collins AC, Marks MJ and Whiteaker P. (2005) Expression of nigrostriatal alpha 6-containing nicotinic acetylcholine receptors is selectively reduced, but not eliminated, by beta 3 subunit gene deletion. Mol. Pharmacol. 67: 2007-15 [PMID:15749993]

93. Gotti C, Moretti M, Zanardi A, Gaimarri A, Champtiaux N, Changeux JP, Whiteaker P, Marks MJ, Clementi F and Zoli M. (2005) Heterogeneity and selective targeting of neuronal nicotinic acetylcholine receptor (nAChR) subtypes expressed on retinal afferents of the superior colliculus and lateral geniculate nucleus: identification of a new native nAChR subtype alpha3beta2(alpha5 or beta3) enriched in retinocollicular afferents. Mol. Pharmacol. 68: 1162-71 [PMID:16049166]

94. Gotti C, Zoli M and Clementi F. (2006) Brain nicotinic acetylcholine receptors: native subtypes and their relevance. Trends Pharmacol. Sci. 27: 482-91 [PMID:16876883]

95. Grady SR, Moretti M, Zoli M, Marks MJ, Zanardi A, Pucci L, Clementi F and Gotti C. (2009) Rodent habenulo-interpeduncular pathway expresses a large variety of uncommon nAChR subtypes, but only the alpha3beta ${ }^{*}$ and alpha3beta3beta4* subtypes mediate acetylcholine release. J. Neurosci. 29: 2272-82 [PMID:19228980]

96. Grady SR, Salminen O, Laverty DC, Whiteaker P, Mclntosh JM, Collins AC and Marks MJ. (2007) The subtypes of nicotinic acetylcholine receptors on dopaminergic terminals of mouse striatum. Biochem. Pharmacol. 74: 1235-46 [PMID:17825262]

97. Grando SA. (2008) Basic and clinical aspects of non-neuronal acetylcholine: biological and clinical significance of non-canonical ligands of epithelial nicotinic acetylcholine receptors. J. Pharmacol. Sci. 106: 
174-9 [PMID:18285656]

98. Han ZY, Le Novère N, Zoli M, Hill JA, Champtiaux N and Changeux JP. (2000) Localization of nAChR subunit mRNAs in the brain of Macaca mulatta. Eur. J. Neurosci. 12: 3664-74 [PMID:11029636]

99. Han ZY, Zoli M, Cardona A, Bourgeois JP, Changeux JP and Le Novère N. (2003) Localization of $[3 \mathrm{H}]$ nicotine, $[3 \mathrm{H}]$ cytisine, [3H]epibatidine, and [125I]alpha-bungarotoxin binding sites in the brain of Macaca mulatta. J. Comp. Neurol. 461: 49-60 [PMID:12722104]

100. Harpsøe K, Ahring PK, Christensen JK, Jensen ML, Peters D and Balle T. (2011) Unraveling the high- and low-sensitivity agonist responses of nicotinic acetylcholine receptors. J. Neurosci. 31: 10759-66 [PMID:21795528]

101. Hauser TA, Kucinski A, Jordan KG, Gatto GJ, Wersinger SR, Hesse RA, Stachowiak EK, Stachowiak MK, Papke RL and Lippiello PM et al.. (2009) TC-5619: an alpha7 neuronal nicotinic receptor-selective agonist that demonstrates efficacy in animal models of the positive and negative symptoms and cognitive dysfunction of schizophrenia. Biochem. Pharmacol. 78: 803-12 [PMID:19482012]

102. Heidmann O, Buonanno A, Geoffroy B, Robert B, Guénet JL, Merlie JP and Changeux JP. (1986) Chromosomal localization of muscle nicotinic acetylcholine receptor genes in the mouse. Science 234: 866-8 [PMID:3022377]

103. Hibbs RE and Gouaux E. (2011) Principles of activation and permeation in an anion-selective Cys-loop receptor. Nature 474: 54-60 [PMID:21572436]

104. Hirose S, Iwata H, Akiyoshi H, Kobayashi K, Ito M, Wada K, Kaneko S and Mitsudome A. (1999) A novel mutation of CHRNA4 responsible for autosomal dominant nocturnal frontal lobe epilepsy. Neurology 53: 1749-53 [PMID:10563623]

105. Hoda JC, Gu W, Friedli M, Phillips HA, Bertrand S, Antonarakis SE, Goudie D, Roberts R, Scheffer IE and Marini $C$ et al.. (2008) Human nocturnal frontal lobe epilepsy: pharmocogenomic profiles of pathogenic nicotinic acetylcholine receptor beta-subunit mutations outside the ion channel pore. Mol. Pharmacol. 74: 379-91 [PMID:18456869]

106. Hoffmann K, Muller JS, Stricker S, Megarbane A, Rajab A, Lindner TH, Cohen M, Chouery E, Adaimy L and Ghanem I et al.. (2006) Escobar syndrome is a prenatal myasthenia caused by disruption of the acetylcholine receptor fetal gamma subunit. Am. J. Hum. Genet. 79: 303-12 [PMID:16826520]

107. Hung RJ, McKay JD, Gaborieau V, Boffetta P, Hashibe M, Zaridze D, Mukeria A, Szeszenia-Dabrowska N, Lissowska J and Rudnai P et al.. (2008) A susceptibility locus for lung cancer maps to nicotinic acetylcholine receptor subunit genes on 15q25. Nature 452: 633-7 [PMID:18385738]

108. Hunt S and Schmidt J. (1978) Some observations on the binding patterns of alpha-bungarotoxin in the central nervous system of the rat. Brain Res. 157: 213-32 [PMID:719523]

109. Hurst RS, Hajós M, Raggenbass M, Wall TM, Higdon NR, Lawson JA, Rutherford-Root KL, Berkenpas MB, Hoffmann WE and Piotrowski DW et al.. (2005) A novel positive allosteric modulator of the alpha7 neuronal nicotinic acetylcholine receptor: in vitro and in vivo characterization. J. Neurosci. 25: 4396-405 [PMID:15858066]

110. Hurth $\mathrm{K}$ and et. al.. MEDI 222: Identification of AQW051, an alpha7 nicotinic acetylcholine receptor partial agonist for the treatment of cognitive impairment associated with schizophrenia.

111. Improgo MR, Scofield MD, Tapper AR and Gardner PD. (2010) The nicotinic acetylcholine receptor CHRNA5/A3/B4 gene cluster: dual role in nicotine addiction and lung cancer. Prog. Neurobiol. 92: 212-26 [PMID:20685379]

112. Ishii K, Wong JK and Sumikawa K. (2005) Comparison of alpha2 nicotinic acetylcholine receptor subunit mRNA expression in the central nervous system of rats and mice. J. Comp. Neurol. 493: 241-60 [PMID:16255031]

113. Jackson KJ, Marks MJ, Vann RE, Chen X, Gamage TF, Warner JA and Damaj MI. (2010) Role of alpha5 nicotinic acetylcholine receptors in pharmacological and behavioral effects of nicotine in mice. $J$. Pharmacol. Exp. Ther. 334: 137-46 [PMID:20400469]

114. Jensen AA, Frølund B, Liljefors T and Krogsgaard-Larsen P. (2005) Neuronal nicotinic acetylcholine receptors: structural revelations, target identifications, and therapeutic inspirations. J. Med. Chem. 48: 
4705-45 [PMID:16033252]

115. Jones AK, Buckingham SD and Sattelle DB. (2010) Proteins interacting with nicotinic acetylcholine receptors: expanding functional and therapeutic horizons. Trends Pharmacol. Sci. 31: 455-62 [PMID:20674046]

116. Jonsson M, Gurley D, Dabrowski M, Larsson O, Johnson EC and Eriksson LI. (2006) Distinct pharmacologic properties of neuromuscular blocking agents on human neuronal nicotinic acetylcholine receptors: a possible explanation for the train-of-four fade. Anesthesiology 105: 521-33 [PMID:16931985]

117. Kalamida D, Poulas K, Avramopoulou V, Fostieri E, Lagoumintzis G, Lazaridis K, Sideri A, Zouridakis M and Tzartos SJ. (2007) Muscle and neuronal nicotinic acetylcholine receptors. Structure, function and pathogenicity. FEBS J. 274: 3799-845 [PMID:17651090]

118. Karlin A. (2002) Emerging structure of the nicotinic acetylcholine receptors.Nat. Rev. Neurosci. 3: 102-14 [PMID:11836518]

119. Kedmi M, Beaudet AL and Orr-Urtreger A. (2004) Mice lacking neuronal nicotinic acetylcholine receptor beta4-subunit and mice lacking both alpha5- and beta4-subunits are highly resistant to nicotine-induced seizures. Physiol. Genomics 17: 221-9 [PMID:14996991]

120. Klaassen A, Glykys J, Maguire J, Labarca C, Mody I and Boulter J. (2006) Seizures and enhanced cortical GABAergic inhibition in two mouse models of human autosomal dominant nocturnal frontal lobe epilepsy. Proc. Natl. Acad. Sci. U.S.A. 103: 19152-7 [PMID:17146052]

121. Krause RM, Buisson B, Bertrand S, Corringer PJ, Galzi JL, Changeux JP and Bertrand D. (1998) Ivermectin: a positive allosteric effector of the alpha7 neuronal nicotinic acetylcholine receptor. Mol. Pharmacol. 53: 283-94 [PMID:9463487]

122. Kulak JM, Carroll FI and Schneider JS. (2006) [125I]lodomethyllycaconitine binds to alpha7 nicotinic acetylcholine receptors in monkey brain. Eur. J. Neurosci. 23: 2604-10 [PMID:16817863]

123. Kulak JM and Schneider JS. (2004) Differences in alpha7 nicotinic acetylcholine receptor binding in motor symptomatic and asymptomatic MPTP-treated monkeys. Brain Res. 999: 193-202 [PMID:14759498]

124. Kuryatov A, Berrettini $W$ and Lindstrom J. (2011) Acetylcholine receptor (AChR) $\propto 5$ subunit variant associated with risk for nicotine dependence and lung cancer reduces $(\alpha 4 \beta 2)_{2} \alpha 5 \mathrm{AChR}$ function. Mol. Pharmacol. 79: 119-25 [PMID:20881005]

125. Kuryatov A, Onksen $\mathrm{J}$ and Lindstrom J. (2008) Roles of accessory subunits in alpha4beta2(*) nicotinic receptors. Mol. Pharmacol. 74: 132-43 [PMID:18381563]

126. Labarca C, Schwarz J, Deshpande P, Schwarz S, Nowak MW, Fonck C, Nashmi R, Kofuji P, Dang H and Shi W et al.. (2001) Point mutant mice with hypersensitive alpha 4 nicotinic receptors show dopaminergic deficits and increased anxiety. Proc. Natl. Acad. Sci. U.S.A. 98: 2786-91 [PMID:11226318]

127. LaPolla RJ, Mayne KM and Davidson N. (1984) Isolation and characterization of a cDNA clone for the complete protein coding region of the delta subunit of the mouse acetylcholine receptor. Proc. Natl. Acad. Sci. U.S.A. 81: 7970-4 [PMID:6096870]

128. Le Novère $N$ and Changeux JP. (1995) Molecular evolution of the nicotinic acetylcholine receptor: an example of multigene family in excitable cells. J. Mol. Evol. 40: 155-72 [PMID:7699721]

129. Le Novère N, Zoli $M$ and Changeux JP. (1996) Neuronal nicotinic receptor alpha 6 subunit mRNA is selectively concentrated in catecholaminergic nuclei of the rat brain. Eur. J. Neurosci. 8: 2428-39 [PMID:8950106]

130. Lee $\mathrm{CH}$, Zhu C, Malysz J, Campbell T, Shaughnessy T, Honore P, Polakowski J and Gopalakrishnan M. (2011) $\alpha 4 \beta 2$ neuronal nicotinic receptor positive allosteric modulation: an approach for improving the therapeutic index of $\alpha 4 \beta 2$ nAChR agonists in pain. Biochem. Pharmacol. 82: 959-66 [PMID:21763685]

131. Leniger T, Kananura C, Hufnagel A, Bertrand S, Bertrand D and Steinlein OK. (2003) A new Chrna4 mutation with low penetrance in nocturnal frontal lobe epilepsy. Epilepsia 44: 981-5 [PMID:12823585]

132. Leonard S, Gault J, Hopkins J, Logel J, Vianzon R, Short M, Drebing C, Berger R, Venn D and Sirota Pet al.. (2002) Association of promoter variants in the alpha7 nicotinic acetylcholine receptor subunit gene with an inhibitory deficit found in schizophrenia. Arch. Gen. Psychiatry 59: 1085-96 [PMID:12470124]

133. Levin ED, Petro A, Rezvani AH, Pollard N, Christopher NC, Strauss M, Avery J, Nicholson J and Rose JE. 
(2009) Nicotinic alpha7- or beta2-containing receptor knockout: effects on radial-arm maze learning and long-term nicotine consumption in mice. Behav. Brain Res. 196: 207-13 [PMID:18831991]

134. Lindstrom JM. (2000) Acetylcholine receptors and myasthenia. Muscle Nerve 23: 453-77 [PMID:10716755]

135. Lips KS, Pfeil $U$ and Kummer W. (2002) Coexpression of alpha 9 and alpha 10 nicotinic acetylcholine receptors in rat dorsal root ganglion neurons. Neuroscience 115: 1-5 [PMID:12401316]

136. Liu Z, Zhang J and Berg DK. (2007) Role of endogenous nicotinic signaling in guiding neuronal development. Biochem. Pharmacol. 74: 1112-9 [PMID:17603025]

137. Livingstone PD and Wonnacott S. (2009) Nicotinic acetylcholine receptors and the ascending dopamine pathways. Biochem. Pharmacol. 78: 744-55 [PMID:19523928]

138. Lu Y, Grady S, Marks MJ, Picciotto M, Changeux JP and Collins AC. (1998) Pharmacological characterization of nicotinic receptor-stimulated GABA release from mouse brain synaptosomes. J. Pharmacol. Exp. Ther. 287: 648-57 [PMID:9808692]

139. Lukas RJ, Changeux JP, Le Novère N, Albuquerque EX, Balfour DJ, Berg DK, Bertrand D, Chiappinelli VA, Clarke PB and Collins AC et al.. (1999) International Union of Pharmacology. XX. Current status of the nomenclature for nicotinic acetylcholine receptors and their subunits. Pharmacol. Rev. 51: 397-401 [PMID:10353988]

140. Lustig LR, Peng H, Hiel H, Yamamoto T and Fuchs PA. (2001) Molecular cloning and mapping of the human nicotinic acetylcholine receptor alpha10 (CHRNA10). Genomics 73: 272-83 [PMID:11350119]

141. Luther MA, Schoepfer R, Whiting P, Casey B, Blatt Y, Montal MS, Montal M and Linstrom J. (1989) A muscle acetylcholine receptor is expressed in the human cerebellar medulloblastoma cell line TE671. $J$. Neurosci. 9: 1082-96 [PMID:2564429]

142. Maehle AH, Prüll CR and Halliwell RF. (2002) The emergence of the drug receptor theory.Nat Rev Drug Discov 1: 637-41 [PMID:12402503]

143. Malysz J, Grønlien JH, Anderson DJ, Håkerud M, Thorin-Hagene K, Ween H, Wetterstrand C, Briggs CA, Faghih R and Bunnelle WH et al.. (2009) In vitro pharmacological characterization of a novel allosteric modulator of alpha 7 neuronal acetylcholine receptor, 4-(5-(4-chlorophenyl)-2-methyl-3-propionyl-1Hpyrrol-1-yl)benzenesulfonamide (A-867744), exhibiting unique pharmacological profile. J. Pharmacol. Exp. Ther. 330: 257-67 [PMID:19389923]

144. Mandelzys A, Pié B, Deneris ES and Cooper E. (1994) The developmental increase in ACh current densities on rat sympathetic neurons correlates with changes in nicotinic ACh receptor alpha-subunit gene expression and occurs independent of innervation. J. Neurosci. 14: 2357-64 [PMID:8158273]

145. Marks MJ, Pauly JR, Gross SD, Deneris ES, Hermans-Borgmeyer I, Heinemann SF and Collins AC. (1992) Nicotine binding and nicotinic receptor subunit RNA after chronic nicotine treatment. J. Neurosci. 12: 2765-84 [PMID:1613557]

146. Marks MJ, Pauly JR, Grun EU and Collins AC. (1996) ST/b and DBA/2 mice differ in brain alphabungarotoxin binding and alpha 7 nicotinic receptor subunit mRNA levels: a quantitative autoradiographic analysis. Brain Res. Mol. Brain Res. 39: 207-22 [PMID:8804729]

147. Marubio LM, del Mar Arroyo-Jimenez M, Cordero-Erausquin M, Léna $C$, Le Novère N, de Kerchove d'Exaerde A, Huchet M, Damaj MI and Changeux JP. (1999) Reduced antinociception in mice lacking neuronal nicotinic receptor subunits. Nature 398: 805-10 [PMID:10235262]

148. Marubio LM, Gardier AM, Durier S, David D, Klink R, Arroyo-Jimenez MM, McIntosh JM, Rossi F, Champtiaux $\mathrm{N}$ and Zoli $\mathrm{M}$ et al.. (2003) Effects of nicotine in the dopaminergic system of mice lacking the alpha4 subunit of neuronal nicotinic acetylcholine receptors. Eur. J. Neurosci. 17: 1329-37 [PMID:12713636]

149. Marubio LM and Paylor R. (2004) Impaired passive avoidance learning in mice lacking central neuronal nicotinic acetylcholine receptors. Neuroscience 129: 575-82 [PMID:15541879]

150. Mazurov AA, Speake JD and Yohannes D. (2011) Discovery and development of $\alpha 7$ nicotinic acetylcholine receptor modulators. J. Med. Chem. 54: 7943-61 [PMID:21919481]

151. Mazzaferro S, Benallegue N, Carbone A, Gasparri F, Vijayan R, Biggin PC, Moroni M and Bermudez I. (2011) Additional acetylcholine (ACh) binding site at alpha4/alpha4 interface of (alpha4beta2)2alpha4 
nicotinic receptor influences agonist sensitivity. J. Biol. Chem. 286: 31043-54 [PMID:21757735]

152. Merlie JP, Sebbane R, Gardner S and Lindstrom J. (1983) cDNA clone for the alpha subunit of the acetylcholine receptor from the mouse muscle cell line BC3H-1. Proc. Natl. Acad. Sci. U.S.A. 80: 3845-9 [PMID:6344089]

153. Michalk A, Stricker S, Becker J, Rupps R, Pantzar T, Miertus J, Botta G, Naretto VG, Janetzki C and Yaqoob $\mathrm{N}$ et al.. (2008) Acetylcholine receptor pathway mutations explain various fetal akinesia deformation sequence disorders. Am. J. Hum. Genet. 82: 464-76 [PMID:18252226]

154. Millar NS. (2008) RIC-3: a nicotinic acetylcholine receptor chaperone.Br. J. Pharmacol. 153 Suppl 1: S177-83 [PMID:18246096]

155. Millar NS and Gotti C. (2009) Diversity of vertebrate nicotinic acetylcholine receptors.Neuropharmacology 56: 237-46 [PMID:18723036]

156. Miller PS and Smart TG. (2010) Binding, activation and modulation of Cys-loop receptors.Trends Pharmacol. Sci. 31: 161-74 [PMID:20096941]

157. Milone M, Wang HL, Ohno K, Fukudome T, Pruitt JN, Bren N, Sine SM and Engel AG. (1997) Slowchannel myasthenic syndrome caused by enhanced activation, desensitization, and agonist binding affinity attributable to mutation in the M2 domain of the acetylcholine receptor alpha subunit. J. Neurosci. 17: 5651-65 [PMID:9221765]

158. Mineur YS, Einstein EB, Seymour PA, Coe JW, O'neill BT, Rollema H and Picciotto MR. (2011) $\alpha 4 \beta 2$ nicotinic acetylcholine receptor partial agonists with low intrinsic efficacy have antidepressant-like properties. Behav Pharmacol 22: 291-9 [PMID:21566524]

159. Missias AC, Mudd J, Cunningham JM, Steinbach JH, Merlie JP and Sanes JR. (1997) Deficient development and maintenance of postsynaptic specializations in mutant mice lacking an 'adult' acetylcholine receptor subunit. Development 124: 5075-86 [PMID:9362465]

160. Monteggia LM, Gopalakrishnan M, Touma E, Idler KB, Nash N, Arneric SP, Sullivan JP and Giordano T. (1995) Cloning and transient expression of genes encoding the human alpha 4 and beta 2 neuronal nicotinic acetylcholine receptor (nAChR) subunits. Gene 155: 189-93 [PMID:7721089]

161. Morgan NV, Brueton LA, Cox P, Greally MT, Tolmie J, Pasha S, Aligianis IA, van Bokhoven H, Marton T and Al-Gazali L et al.. (2006) Mutations in the embryonal subunit of the acetylcholine receptor (CHRNG) cause lethal and Escobar variants of multiple pterygium syndrome. Am. J. Hum. Genet.79: 390-5 [PMID:16826531]

162. Morley BJ, Li HS, Hiel H, Drescher DG and Elgoyhen AB. (1998) Identification of the subunits of the nicotinic cholinergic receptors in the rat cochlea using RT-PCR and in situ hybridization. Brain Res. Mol. Brain Res. 53: 78-87 [PMID:9473597]

163. Murthy V, Taranda J, Elgoyhen AB and Vetter DE. (2009) Activity of nAChRs containing alpha9 subunits modulates synapse stabilization via bidirectional signaling programs. Dev Neurobio/69: 931-49 [PMID:19790106]

164. Müller JS, Baumeister SK, Schara U, Cossins J, Krause S, von der Hagen M, Huebner A, Webster R, Beeson D and Lochmüller $\mathrm{H}$ et al.. (2006) CHRND mutation causes a congenital myasthenic syndrome by impairing co-clustering of the acetylcholine receptor with rapsyn. Brain 129: 2784-93 [PMID:16916845]

165. Nakauchi S, Brennan RJ, Boulter J and Sumikawa K. (2007) Nicotine gates long-term potentiation in the hippocampal CA1 region via the activation of alpha2* nicotinic ACh receptors. Eur. J. Neurosci. 25: 266681 [PMID:17466021]

166. Nguyen VT, Ndoye A and Grando SA. (2000) Novel human alpha9 acetylcholine receptor regulating keratinocyte adhesion is targeted by Pemphigus vulgaris autoimmunity. Am. J. Pathol. 157: 1377-91 [PMID:11021840]

167. No authors listed. (2004) Natalizumab: AN 100226, anti-4alpha integrin monoclonal antibody.Drugs $R D$ 5: 102-7 [PMID:15293871]

168. Noda M, Furutani $Y$, Takahashi H, Toyosato M, Tanabe T, Shimizu S, Kikyotani S, Kayano T, Hirose T and Inayama $S$ et al.. (1983) Cloning and sequence analysis of calf cDNA and human genomic DNA encoding alpha-subunit precursor of muscle acetylcholine receptor. Nature 305: 818-23 [PMID:6688857] 
169. Ohno K, Hutchinson DO, Milone M, Brengman JM, Bouzat C, Sine SM and Engel AG. (1995) Congenital myasthenic syndrome caused by prolonged acetylcholine receptor channel openings due to a mutation in the M2 domain of the epsilon subunit. Proc. Natl. Acad. Sci. U.S.A. 92: 758-62 [PMID:7531341]

170. Ohno K, Wang HL, Milone M, Bren N, Brengman JM, Nakano S, Quiram P, Pruitt JN, Sine SM and Engel AG. (1996) Congenital myasthenic syndrome caused by decreased agonist binding affinity due to a mutation in the acetylcholine receptor epsilon subunit. Neuron 17: 157-70 [PMID:8755487]

171. Orr-Urtreger A, Broide RS, Kasten MR, Dang H, Dani JA, Beaudet AL and Patrick JW. (2000) Mice homozygous for the L250T mutation in the alpha7 nicotinic acetylcholine receptor show increased neuronal apoptosis and die within 1 day of birth. J. Neurochem. 74: 2154-66 [PMID:10800961]

172. Orr-Urtreger A, Göldner FM, Saeki M, Lorenzo I, Goldberg L, De Biasi M, Dani JA, Patrick JW and Beaudet AL. (1997) Mice deficient in the alpha7 neuronal nicotinic acetylcholine receptor lack alphabungarotoxin binding sites and hippocampal fast nicotinic currents. J. Neurosci. 17: 9165-71 [PMID:9364063]

173. Orr-Urtreger A, Seldin MF, Baldini A and Beaudet AL. (1995) Cloning and mapping of the mouse alpha 7neuronal nicotinic acetylcholine receptor. Genomics 26: 399-402 [PMID:7601470]

174. Palma E, Bertrand S, Binzoni T and Bertrand D. (1996) Neuronal nicotinic alpha 7 receptor expressed in Xenopus oocytes presents five putative binding sites for methyllycaconitine. J. Physiol. (Lond.) 491 ( Pt 1): 151-61 [PMID:9011607]

175. Papke RL, Dwoskin LP, Crooks PA, Zheng G, Zhang Z, Mclntosh JM and Stokes C. (2008) Extending the analysis of nicotinic receptor antagonists with the study of alpha6 nicotinic receptor subunit chimeras. Neuropharmacology 54: 1189-200 [PMID:18448138]

176. Papke RL, Sanberg PR and Shytle RD. (2001) Analysis of mecamylamine stereoisomers on human nicotinic receptor subtypes. J. Pharmacol. Exp. Ther. 297: 646-56 [PMID:11303054]

177. Paul M, Kindler CH, Fokt RM, Dresser MJ, Dipp NC and Yost CS. (2002) The potency of new muscle relaxants on recombinant muscle-type acetylcholine receptors. Anesth. Analg. 94: 597-603; table of contents [PMID:11867382]

178. Pauly JR, Stitzel JA, Marks MJ and Collins AC. (1989) An autoradiographic analysis of cholinergic receptors in mouse brain. Brain Res. Bull. 22: 453-9 [PMID:2706548]

179. Philips A, Lesage S, Gingras R, Maira MH, Gauthier Y, Hugo P and Drouin J. (1997) Novel dimeric Nur77 signaling mechanism in endocrine and lymphoid cells. Mol. Cell. Biol. 17: 5946-51 [PMID:9315652]

180. Phillips HA, Favre I, Kirkpatrick M, Zuberi SM, Goudie D, Heron SE, Scheffer IE, Sutherland GR, Berkovic SF and Bertrand D et al.. (2001) CHRNB2 is the second acetylcholine receptor subunit associated with autosomal dominant nocturnal frontal lobe epilepsy. Am. J. Hum. Genet. 68: 225-31 [PMID:11104662]

181. Phillips HA, Marini C, Scheffer IE, Sutherland GR, Mulley JC and Berkovic SF. (2000) A de novo mutation in sporadic nocturnal frontal lobe epilepsy. Ann. Neurol. 48: 264-7 [PMID:10939581]

182. Picciotto $M R$, Zoli $M$, Léna $C$, Bessis $A$, Lallemand $Y$, Le Novère $N$, Vincent $P$, Pich $E M$, Brûlet $P$ and Changeux JP. (1995) Abnormal avoidance learning in mice lacking functional high-affinity nicotine receptor in the brain. Nature 374: 65-7 [PMID:7870173]

183. Picciotto MR, Zoli M, Rimondini R, Léna C, Marubio LM, Pich EM, Fuxe K and Changeux JP. (1998) Acetylcholine receptors containing the beta2 subunit are involved in the reinforcing properties of nicotine. Nature 391: 173-7 [PMID:9428762]

184. Poth K, Nutter TJ, Cuevas J, Parker MJ, Adams DJ and Luetje CW. (1997) Heterogeneity of nicotinic receptor class and subunit mRNA expression among individual parasympathetic neurons from rat intracardiac ganglia. J. Neurosci. 17: 586-96 [PMID:8987781]

185. Prickaerts J, van Goethem NP, Chesworth R, Shapiro G, Boess FG, Methfessel C, Reneerkens OA, Flood DG, Hilt D and Gawryl M et al.. (2012) EVP-6124, a novel and selective $\alpha 7$ nicotinic acetylcholine receptor partial agonist, improves memory performance by potentiating the acetylcholine response of $\alpha 7$ nicotinic acetylcholine receptors. Neuropharmacology 62: 1099-110 [PMID:22085888]

186. Quik M, Polonskaya Y, Gillespie A, Jakowec M, Lloyd GK and Langston JW. (2000) Localization of nicotinic receptor subunit mRNAs in monkey brain by in situ hybridization. J. Comp. Neurol. 425: 58-69 
[PMID:10940942]

187. Quiram PA, Ohno K, Milone M, Patterson MC, Pruitt NJ, Brengman JM, Sine SM and Engel AG. (1999) Mutation causing congenital myasthenia reveals acetylcholine receptor beta/delta subunit interaction essential for assembly. J. Clin. Invest. 104: 1403-10 [PMID:10562302]

188. Raimondi E, Rubboli F, Moralli D, Chini B, Fornasari D, Tarroni P, De Carli L and Clementi F. (1992) Chromosomal localization and physical linkage of the genes encoding the human alpha 3 , alpha 5 , and beta 4 neuronal nicotinic receptor subunits. Genomics 12: 849-50 [PMID:1572664]

189. Romero HK, Christensen SB, Di Cesare Mannelli L, Gajewiak J, Ramachandra R, Elmslie KS, Vetter DE, Ghelardini C, ladonato SP and Mercado JL et al.. (2017) Inhibition of $\alpha 9 \alpha 10$ nicotinic acetylcholine receptors prevents chemotherapy-induced neuropathic pain. Proc. Natl. Acad. Sci. U.S.A. 114: E1825E1832 [PMID:28223528]

190. Ross SA, Wong JY, Clifford JJ, Kinsella A, Massalas JS, Horne MK, Scheffer IE, Kola I, Waddington JL and Berkovic SF et al.. (2000) Phenotypic characterization of an alpha 4 neuronal nicotinic acetylcholine receptor subunit knock-out mouse. J. Neurosci. 20: 6431-41 [PMID:10964949]

191. Rossi FM, Pizzorusso T, Porciatti V, Marubio LM, Maffei L and Changeux JP. (2001) Requirement of the nicotinic acetylcholine receptor beta 2 subunit for the anatomical and functional development of the visual system. Proc. Natl. Acad. Sci. U.S.A. 98: 6453-8 [PMID:11344259]

192. Rubboli F, Court JA, Sala C, Morris C, Chini B, Perry E and Clementi F. (1994) Distribution of nicotinic receptors in the human hippocampus and thalamus. Eur. J. Neurosci. 6: 1596-604 [PMID:7850023]

193. Rucktooa $P$, Smit AB and Sixma TK. (2009) Insight in $n A C h R$ subtype selectivity from AChBP crystal structures. Biochem. Pharmacol. 78: 777-87 [PMID:19576182]

194. Rust G, Burgunder JM, Lauterburg TE and Cachelin AB. (1994) Expression of neuronal nicotinic acetylcholine receptor subunit genes in the rat autonomic nervous system. Eur. J. Neurosci. 6: 478-85 [PMID:8019684]

195. Sabatelli M, Eusebi F, Al-Chalabi A, Conte A, Madia F, Luigetti M, Mancuso I, Limatola C, Trettel F and Sobrero $\mathrm{F}$ et al.. (2009) Rare missense variants of neuronal nicotinic acetylcholine receptor altering receptor function are associated with sporadic amyotrophic lateral sclerosis. Hum. Mol. Genet. 18: 39974006 [PMID:19628475]

196. Saccone SF, Hinrichs AL, Saccone NL, Chase GA, Konvicka K, Madden PA, Breslau N, Johnson EO, Hatsukami D and Pomerleau $O$ et al.. (2007) Cholinergic nicotinic receptor genes implicated in a nicotine dependence association study targeting 348 candidate genes with 3713 SNPs. Hum. Mol. Genet. 16: 3649 [PMID:17135278]

197. Salas R, Cook KD, Bassetto $L$ and De Biasi M. (2004) The alpha3 and beta4 nicotinic acetylcholine receptor subunits are necessary for nicotine-induced seizures and hypolocomotion in mice. Neuropharmacology 47: 401-7 [PMID:15275829]

198. Salas R, Orr-Urtreger A, Broide RS, Beaudet A, Paylor R and De Biasi M. (2003) The nicotinic acetylcholine receptor subunit alpha 5 mediates short-term effects of nicotine in vivo. Mol. Pharmacol. 63: 1059-66 [PMID:12695534]

199. Salas R, Pieri F and De Biasi M. (2004) Decreased signs of nicotine withdrawal in mice null for the beta4 nicotinic acetylcholine receptor subunit. J. Neurosci. 24: 10035-9 [PMID:15537871]

200. Salas R, Pieri F, Fung B, Dani JA and De Biasi M. (2003) Altered anxiety-related responses in mutant mice lacking the beta4 subunit of the nicotinic receptor. J. Neurosci. 23: 6255-63 [PMID:12867510]

201. Scholze P, Ciuraszkiewicz A, GroessI F, Orr-Urtreger A, McIntosh JM and Huck S. (2011) $\alpha 4 \beta 2$ nicotinic acetylcholine receptors in the early postnatal mouse superior cervical ganglion. Dev Neurobio/71: 390-9 [PMID:21485013]

202. Segal M, Dudai $Y$ and Amsterdam A. (1978) Distribution of an alpha-bungarotoxin-binding cholinergic nicotinic receptor in rat brain. Brain Res. 148: 105-19 [PMID:656919]

203. Sgard F, Charpantier E, Bertrand S, Walker N, Caput D, Graham D, Bertrand D and Besnard F. (2002) A novel human nicotinic receptor subunit, alpha10, that confers functionality to the alpha9-subunit. Mol.

Pharmacol. 61: 150-9 [PMID:11752216] 
204. Shao XM, Tan W, Xiu J, Puskar N, Fonck C, Lester HA and Feldman JL. (2008) Alpha4* nicotinic receptors in preBotzinger complex mediate cholinergic/nicotinic modulation of respiratory rhythm. $J$. Neurosci. 28: 519-28 [PMID:18184794]

205. Shen XM, Brengman JM, Edvardson S, Sine SM and Engel AG. (2012) Highly fatal fast-channel syndrome caused by AChR $\varepsilon$ subunit mutation at the agonist binding site. Neurology 79: 449-54 [PMID:22592360]

206. Shen XM, Deymeer F, Sine SM and Engel AG. (2006) Slow-channel mutation in acetylcholine receptor alphaM4 domain and its efficient knockdown. Ann. Neurol. 60: 128-36 [PMID:16685696]

207. Shen XM, Fukuda T, Ohno K, Sine SM and Engel AG. (2008) Congenital myasthenia-related AChR delta subunit mutation interferes with intersubunit communication essential for channel gating. J. Clin. Invest. 118: 1867-76 [PMID:18398509]

208. Shen XM, Ohno K, Fukudome T, Tsujino A, Brengman JM, De Vivo DC, Packer RJ and Engel AG. (2002) Congenital myasthenic syndrome caused by low-expressor fast-channel AChR delta subunit mutation. Neurology 59: 1881-8 [PMID:12499478]

209. Shibahara S, Kubo T, Perski HJ, Takahashi H, Noda M and Numa S. (1985) Cloning and sequence analysis of human genomic DNA encoding gamma subunit precursor of muscle acetylcholine receptor. Eur. J. Biochem. 146: 15-22 [PMID:3967651]

210. Sine SM and Engel AG. (2006) Recent advances in Cys-loop receptor structure and function.Nature 440: 448-55 [PMID:16554804]

211. Sine SM, Ohno K, Bouzat C, Auerbach A, Milone M, Pruitt JN and Engel AG. (1995) Mutation of the acetylcholine receptor alpha subunit causes a slow-channel myasthenic syndrome by enhancing agonist binding affinity. Neuron 15: 229-39 [PMID:7619526]

212. Smit AB, Brejc K, Syed N and Sixma TK. (2003) Structure and function of AChBP, homologue of the ligand-binding domain of the nicotinic acetylcholine receptor. Ann. N. Y. Acad. Sci. 998: 81-92 [PMID:14592865]

213. Son JH and Winzer-Serhan UH. (2006) Postnatal expression of alpha2 nicotinic acetylcholine receptor subunit mRNA in developing cortex and hippocampus. J. Chem. Neuroanat. 32: 179-90 [PMID:17046198]

214. Steinlein OK and Bertrand D. (2008) Neuronal nicotinic acetylcholine receptors: from the genetic analysis to neurological diseases. Biochem. Pharmacol. 76: 1175-83 [PMID:18691557]

215. Steinlein OK, Magnusson A, Stoodt J, Bertrand S, Weiland S, Berkovic SF, Nakken KO, Propping P and Bertrand D. (1997) An insertion mutation of the CHRNA4 gene in a family with autosomal dominant nocturnal frontal lobe epilepsy. Hum. Mol. Genet. 6: 943-7 [PMID:9175743]

216. Steinlein OK, Mulley JC, Propping P, Wallace RH, Phillips HA, Sutherland GR, Scheffer IE and Berkovic SF. (1995) A missense mutation in the neuronal nicotinic acetylcholine receptor alpha 4 subunit is associated with autosomal dominant nocturnal frontal lobe epilepsy. Nat. Genet. 11: 201-3 [PMID:7550350]

217. Strømgaard K, Mellor IR, Andersen K, Neagoe I, Pluteanu F, Usherwood PN, Krogsgaard-Larsen P and Jaroszewski JW. (2002) Solid-phase synthesis and pharmacological evaluation of analogues of PhTX-12A potent and selective nicotinic acetylcholine receptor antagonist. Bioorg. Med. Chem. Lett. 12: 1159-62 [PMID:11934578]

218. Séguéla P, Wadiche J, Dineley-Miller K, Dani JA and Patrick JW. (1993) Molecular cloning, functional properties, and distribution of rat brain alpha 7 : a nicotinic cation channel highly permeable to calcium. $J$. Neurosci. 13: 596-604 [PMID:7678857]

219. Takahashi M, Kubo T, Mizoguchi A, Carlson CG, Endo K and Ohnishi K. (2002) Spontaneous muscle action potentials fail to develop without fetal-type acetylcholine receptors. EMBO Rep. 3: 674-81 [PMID:12101101]

220. Taly A, Corringer PJ, Guedin D, Lestage P and Changeux JP. (2009) Nicotinic receptors: allosteric transitions and therapeutic targets in the nervous system. Nat Rev Drug Discov 8: 733-50 [PMID:19721446]

221. Tapper AR, McKinney SL, Marks MJ and Lester HA. (2007) Nicotine responses in hypersensitive and knockout alpha 4 mice account for tolerance to both hypothermia and locomotor suppression in wild-type mice. Physiol. Genomics 31: 422-8 [PMID:17712039] 
222. Tapper AR, McKinney SL, Nashmi R, Schwarz J, Deshpande P, Labarca C, Whiteaker P, Marks MJ, Collins AC and Lester HA. (2004) Nicotine activation of alpha4* receptors: sufficient for reward, tolerance, and sensitization. Science 306: 1029-32 [PMID:15528443]

223. Teper Y, Whyte D, Cahir E, Lester HA, Grady SR, Marks MJ, Cohen BN, Fonck C, McClure-Begley T and Mclntosh JM et al.. (2007) Nicotine-induced dystonic arousal complex in a mouse line harboring a human autosomal-dominant nocturnal frontal lobe epilepsy mutation. J. Neurosci. 27: 10128-42 [PMID:17881519]

224. Thorgeirsson TE, Geller F, Sulem P, Rafnar T, Wiste A, Magnusson KP, Manolescu A, Thorleifsson G, Stefansson $\mathrm{H}$ and Ingason A et al.. (2008) A variant associated with nicotine dependence, lung cancer and peripheral arterial disease. Nature 452: 638-42 [PMID:18385739]

225. Timmermann DB, Grønlien JH, Kohlhaas KL, Nielsen EØ, Dam E, Jørgensen TD, Ahring PK, Peters D, Holst $\mathrm{D}$ and Christensen JK et al.. (2007) An allosteric modulator of the alpha7 nicotinic acetylcholine receptor possessing cognition-enhancing properties in vivo. J. Pharmacol. Exp. Ther. 323: 294-307 [PMID:17625074]

226. Unwin N. (2005) Refined structure of the nicotinic acetylcholine receptor at 4 A resolution J. Mol. Biol. 346: 967-89 [PMID:15701510]

227. van Maanen MA, Stoof SP, Larosa GJ, Vervoordeldonk MJ and Tak PP. (2010) Role of the cholinergic nervous system in rheumatoid arthritis: aggravation of arthritis in nicotinic acetylcholine receptor alpha7 subunit gene knockout mice. Ann. Rheum. Dis. 69: 1717-23 [PMID:20511609]

228. Vetter DE, Katz E, Maison SF, Taranda J, Turcan S, Ballestero J, Liberman MC, Elgoyhen AB and Boulter J. (2007) The alpha10 nicotinic acetylcholine receptor subunit is required for normal synaptic function and integrity of the olivocochlear system. Proc. Natl. Acad. Sci. U.S.A. 104: 20594-9 [PMID:18077337]

229. Vetter DE, Liberman MC, Mann J, Barhanin J, Boulter J, Brown MC, Saffiote-Kolman J, Heinemann SF and Elgoyhen AB. (1999) Role of alpha9 nicotinic ACh receptor subunits in the development and function of cochlear efferent innervation. Neuron 23: 93-103 [PMID:10402196]

230. Wada E, McKinnon D, Heinemann S, Patrick J and Swanson LW. (1990) The distribution of mRNA encoded by a new member of the neuronal nicotinic acetylcholine receptor gene family (alpha 5) in the rat central nervous system. Brain Res. 526: 45-53 [PMID:2078817]

231. Wada E, Wada K, Boulter J, Deneris E, Heinemann S, Patrick J and Swanson LW. (1989) Distribution of alpha 2, alpha 3, alpha 4, and beta 2 neuronal nicotinic receptor subunit mRNAs in the central nervous system: a hybridization histochemical study in the rat. J. Comp. Neurol. 284: 314-35 [PMID:2754038]

232. Wada K, Ballivet M, Boulter J, Connolly J, Wada E, Deneris ES, Swanson LW, Heinemann S and Patrick J. (1988) Functional expression of a new pharmacological subtype of brain nicotinic acetylcholine receptor. Science 240: 330-4 [PMID:2832952]

233. Wang HL, Milone M, Ohno K, Shen XM, Tsujino A, Batocchi AP, Tonali P, Brengman J, Engel AG and Sine SM. (1999) Acetylcholine receptor M3 domain: stereochemical and volume contributions to channel gating. Nat. Neurosci. 2: 226-33 [PMID:10195214]

234. Wang HL, Ohno K, Milone M, Brengman JM, Evoli A, Batocchi AP, Middleton LT, Christodoulou K, Engel AG and Sine SM. (2000) Fundamental gating mechanism of nicotinic receptor channel revealed by mutation causing a congenital myasthenic syndrome. J. Gen. Physiol. 116: 449-62 [PMID:10962020]

235. Wang N, Orr-Urtreger A, Chapman J, Rabinowitz R and Korczyn AD. (2003) Deficiency of nicotinic acetylcholine receptor beta 4 subunit causes autonomic cardiac and intestinal dysfunction. Mol. Pharmacol. 63: 574-80 [PMID:12606764]

236. Wang N, Orr-Urtreger A, Chapman J, Rabinowitz R and Korczyn AD. (2004) Nicotinic acetylcholine receptor alpha5 subunits modulate oxotremorine-induced salivation and tremor. J. Neurol. Sci. 222: 87-91 [PMID:15240201]

237. Wang N, Orr-Urtreger A, Chapman J, Rabinowitz R, Nachman R and Korczyn AD. (2002) Autonomic function in mice lacking alpha5 neuronal nicotinic acetylcholine receptor subunit. J. Physiol. (Lond.) 542: 347-54 [PMID:12122136]

238. Weiland S, Witzemann V, Villarroel A, Propping P and Steinlein O. (1996) An amino acid exchange in the second transmembrane segment of a neuronal nicotinic receptor causes partial epilepsy by altering its 
desensitization kinetics. FEBS Lett. 398: 91-6 [PMID:8946959]

239. Wessler I and Kirkpatrick CJ. (2008) Acetylcholine beyond neurons: the non-neuronal cholinergic system in humans. Br. J. Pharmacol. 154: 1558-71 [PMID:18500366]

240. Whiteaker P, Cooper JF, Salminen O, Marks MJ, McClure-Begley TD, Brown RW, Collins AC and Lindstrom JM. (2006) Immunolabeling demonstrates the interdependence of mouse brain alpha4 and beta2 nicotinic acetylcholine receptor subunit expression. J. Comp. Neurol. 499: 1016-38 [PMID:17072836]

241. Whiteaker P, Jimenez M, Mclntosh JM, Collins AC and Marks MJ. (2000) Identification of a novel nicotinic binding site in mouse brain using [(125)I]-epibatidine. Br. J. Pharmacol. 131: 729-39 [PMID:11030722]

242. Whiteaker P, Peterson CG, Xu W, Mclntosh JM, Paylor R, Beaudet AL, Collins AC and Marks MJ. (2002) Involvement of the alpha3 subunit in central nicotinic binding populations. J. Neurosci. 22: 2522-9 [PMID:11923417]

243. Whiteaker P, Wilking JA, Brown RW, Brennan RJ, Collins AC, Lindstrom JM and Boulter J. (2009) Pharmacological and immunochemical characterization of alpha2* nicotinic acetylcholine receptors (nAChRs) in mouse brain. Acta Pharmacol. Sin. 30: 795-804 [PMID:19498420]

244. Williams DK, Wang J and Papke RL. (2011) Positive allosteric modulators as an approach to nicotinic acetylcholine receptor-targeted therapeutics: advantages and limitations. Biochem. Pharmacol. 82: 915-30 [PMID:21575610]

245. Willoughby JJ, Ninkina NN, Beech MM, Latchman DS and Wood JN. (1993) Molecular cloning of a human neuronal nicotinic acetylcholine receptor beta 3-like subunit. Neurosci. Lett. 155: 136-9 [PMID:7690916]

246. Wishka DG, Walker DP, Yates KM, Reitz SC, Jia S, Myers JK, Olson KL, Jacobsen EJ, Wolfe ML and Groppi VE et al.. (2006) Discovery of N-[(3R)-1-azabicyclo[2.2.2]oct-3-yl]furo[2,3-c]pyridine-5-carboxamide, an agonist of the alpha7 nicotinic acetylcholine receptor, for the potential treatment of cognitive deficits in schizophrenia: synthesis and structure--activity relationship. J. Med. Chem. 49: 4425-36 [PMID:16821801]

247. Witzemann V, Schwarz H, Koenen M, Berberich C, Villarroel A, Wernig A, Brenner HR and Sakmann B. (1996) Acetylcholine receptor epsilon-subunit deletion causes muscle weakness and atrophy in juvenile and adult mice. Proc. Natl. Acad. Sci. U.S.A. 93: 13286-91 [PMID:8917583]

248. Witzemann V, Stein E, Barg B, Konno T, Koenen M, Kues W, Criado M, Hofmann M and Sakmann B. (1990) Primary structure and functional expression of the alpha-, beta-, gamma-, delta- and epsilonsubunits of the acetylcholine receptor from rat muscle. Eur. J. Biochem. 194: 437-48 [PMID:1702709]

249. Wong JY, Ross SA, McColl C, Massalas JS, Powney E, Finkelstein DI, Clark M, Horne MK, Berkovic SF and Drago J. (2002) Proconvulsant-induced seizures in alpha(4) nicotinic acetylcholine receptor subunit knockout mice. Neuropharmacology 43: 55-64 [PMID:12213259]

250. Wood S, Schertzer M and Yaremko ML. (1995) Identification of the human neuronal nicotinic cholinergic alpha 2 receptor locus, (CHRNA2), within an 8p21 mapped locus, by sequence homology with rat DNA. Somat. Cell Mol. Genet. 21: 147-50 [PMID:7570187]

251. Wu J, Liu Q, Yu K, Hu J, Kuo YP, Segerberg M, St John PA and Lukas RJ. (2006) Roles of nicotinic acetylcholine receptor beta subunits in function of human alpha4-containing nicotinic receptors. J. Physiol. (Lond.) 576: 103-18 [PMID:16825297]

252. Wu J and Lukas RJ. (2011) Naturally-expressed nicotinic acetylcholine receptor subtypes.Biochem. Pharmacol. 82: 800-7 [PMID:21787755]

253. Xu C, Lu Y, Tang G and Wang R. (1999) Expression of voltage-dependent $\mathrm{K}(+)$ channel genes in mesenteric artery smooth muscle cells. Am. J. Physiol. 277: G1055-63 [PMID:10564112]

254. Xu W, Gelber S, Orr-Urtreger A, Armstrong D, Lewis RA, Ou CN, Patrick J, Role L, De Biasi M and Beaudet AL. (1999) Megacystis, mydriasis, and ion channel defect in mice lacking the alpha3 neuronal nicotinic acetylcholine receptor. Proc. Natl. Acad. Sci. U.S.A. 96: 5746-51 [PMID:10318955]

255. Xu W, Orr-Urtreger A, Nigro F, Gelber S, Sutcliffe CB, Armstrong D, Patrick JW, Role LW, Beaudet AL and De Biasi M. (1999) Multiorgan autonomic dysfunction in mice lacking the beta2 and the beta4 subunits of neuronal nicotinic acetylcholine receptors. J. Neurosci. 19: 9298-305 [PMID:10531434]

256. Yang KC, Jin GZ and Wu J. (2009) Mysterious alpha6-containing nAChRs: function, pharmacology, and pathophysiology. Acta Pharmacol. Sin. 30: 740-51 [PMID:19498417] 
257. Young GT, Zwart R, Walker AS, Sher E and Millar NS. (2008) Potentiation of alpha7 nicotinic acetylcholine receptors via an allosteric transmembrane site. Proc. Natl. Acad. Sci. U.S.A. 105: 14686-91 [PMID:18791069]

258. Young JW, Crawford N, Kelly JS, Kerr LE, Marston HM, Spratt C, Finlayson K and Sharkey J. (2007) Impaired attention is central to the cognitive deficits observed in alpha 7 deficient mice. Eur Neuropsychopharmacol 17: 145-55 [PMID:16650968]

259. Zhu G, Okada M, Yoshida S, Ueno S, Mori F, Takahara T, Saito R, Miura Y, Kishi A and Tomiyama Met al.. (2008) Rats harboring S284L Chrna4 mutation show attenuation of synaptic and extrasynaptic GABAergic transmission and exhibit the nocturnal frontal lobe epilepsy phenotype. J. Neurosci. 28: 1246576 [PMID:19020039]

260. Zoli M, Picciotto MR, Ferrari R, Cocchi D and Changeux JP. (1999) Increased neurodegeneration during ageing in mice lacking high-affinity nicotine receptors. EMBO J. 18: 1235-44 [PMID:10064590] 